\title{
Theorising Practice and Developing Practically Relevant Insights in Organisational Research
}

In management research, theoretical abstractions, which are traditionally derived based on economic and individualist ontological assumptions, are limited in the ability to produce practically relevant insights and increase the divide between organisational practitioners and scientists. This paper argues that contemporary theory of practice, which jointly considers agency, structure and materiality, overcomes the confrontation and integrates scientific rigour with the richness of organisational practice. The author thereby introduces the origins of practice theory, analyses the definition of practice and explores the areas of management research where practice theory is currently adopted.

Keywords: practice theory, social ontology, organisational studies, social practices, practically relevant scientific knowledge.

Tradicinès vadybos teorijos remiasi ekonominiu požiūriu ir susiduria su praktinio pritaikomumo daugiadimensinëje organizacijų aplinkoje sunkumais. Praktikos teorija yra viena naujausių šiuolaikiniu mokslinių perspektyvų, kuri jungia žmogaus, struktūrinius ir materialinius pasaulius, kurioje organizaciniai procesai analizuojami suvienijant praktinès organizacijos narių veiklos turtingumą su moksliniu pagrịstumu. Straipsnyje išplètojamas praktikos teorijos apibrèžimas, pristatomas jos kilmės šaknys bei apžvelgiamos vadybos ir organizacijos mokslo sritys, kuriose praktikos teorija jau yra naudojama.

Raktiniai žodžiai: praktikos teorija, socialinè teorija, organizacijų tyrimai, socialinès praktikos, praktinis vadybos mokslo pritaikomumas.

\section{Introduction}

Abundant scientific explorations attempt to explain organisational dynamics based on individual or institutional presumptions but find it difficult to translate those theoretical accounts into practically relevant insights and specific contexts (Gherardi, 2008). Management theories widely adopt an economic approach, which is based on individualist ontology and explanation of human behaviour, in order to analyse organisational processes. Two pillars uphold contemporary management theories: transaction cost (Williamson, 1989) and resource-based (Barney, 1991) approaches, and these drive much of the progress of the discipline. The principles of transactional economics focus on the economic value of how organisations function, exchanges between individuals and environmental forces, which organisations control to their own advantage. The Resource-based view draws attention to the internal capabilities and unique characteristics of firms which help them to 
achieve their targets. The two approaches, as well as others, such as dynamic capabilities (Teece, Pisano, Shuen, 1997), contingency (Lawrence, Lorsch, 1986) or evolutionary (Nelson, Winter, 2009) theories explain organisational dynamics not only in isolation but also by integrating their approaches to strengthen the explanatory power of their theorisations. Also, variety of measures are directed towards improving the production and communication of scientific knowledge: collaborative forms of research between practitioners and scientists and incentives for successful knowledge transfer are considered the ways to close the gap (Sandberg, Tsoukas, 2011). However, these measures do not touch on how scientific knowledge is derived from empirical investigations and use the same scientific individualist approach to the practice of organisations.

The dominance of scientific theorising prompted the rise of an alternative socioontological approach to management and organisational research, which attends to practice as a source of scientific thought and strives to derive theories based on practical theorising (Sandberg, Tsoukas, 2015). Since 1970, multiple scholars turned to practice as a central concept and the primary unit of analysis (Gherardi, 2008; Nicolini, 2012; Ortner, 1984) and, along with this, changed the locus of analysis by supplanting the duality between the individual and social structures. This new approach to building theory engages practical activities as a source and tool for the creation of new knowledge about organisations rather than downgrading it to an informant's role. In Lithuania, practice-oriented approaches have received some interest in recent philosophical and sociological works. For example, Evaldas Juozelis discusses practo-theory (in Lithuanian: "praktoteorija") as an alternative "academic attitude" to scientific knowledge (2016, p. 231), while A. Valantiejus qualifies practice turn (in Lithuanian: "praktinis 'posūkis"') as a part of the microsocial paradigm in his analysis of social (Valantiejus, 2006) and reflexive structures (Valantiejus, 2013). However, similarly to global trends, management and organisational research in Lithuania is still largely grounded in individualistic and economic explanation of human behaviour, which is seen as potentially productive but difficult to implement in actual organisational contexts (Andriuščenka, 2008), thus it stands to benefit from the adoption of practice theory as a complementary perspective in empirical and theoretical explorations.

Therefore, in this paper, practice theory is introduced as an alternative research lens to the economic theories - a lens which enables theorising through the analysis of practice and joint consideration of agency, social structures and materiality. The intention is not to juxtapose or replace economic or sociological accounts but to complement these with the holistic account of organisation as a complex social phenomenon. My aim and desired contribution of this paper is to show how practice theory enriches scientific theorising through understanding of human activities and, by doing this, I want to draw the attention of Lithuanian management scholars and encourage the empirical explorations of management and organisational phenomena through applying practice theoretical lens in their research. Therefore, I carry out an overview of 
practice theory literature in management and organisational science and present the definition of practice theory and practice concept, explain key characteristics of practice as used in management and organisation science; moreover, I outline how these all together help organisational scholars to theorise practice as opposed to the dominant way of scientific theorising.

The object of research is theorising in management and organisational research which would allow to produce practically relevant insights.

The goal of research is to introduce practice theory - the socio-ontological lens - which integrates scientific rigour and the richness of organisational practice. This is accomplished by analysing the origins of practice theory, practice definition and the ways the practice lens is currently applied in management research.

Research methods. The argumentative review of practice theory in organisational studies and its philosophical and sociological underpinnings, and the analysis of exemplars of practice-based studies.

\section{Conceptual roots of practice theory}

As often noted, attention to human practices in science is not new, but rather forgotten and regaining its momentum in the past few decades (Miettinen, Samra-Fredericks, Yanow, 2009; Nicolini, 2012; Schatzki, Knorr-Cetina, von Savigny, 2001). Practice as a distinct kind of knowledge has received attention since Aristotle (Nicolini, 2011) but was isolated as independent from theoretical epistemic objects and from the human mind
(Nicolini, 2012; van Inwagen, 2001) until the extreme idealist immaterialism was challenged by a new conception of materiality and questioning the distinction between mind and bodily activities. Karl Marx proclaimed an interest in activities that people do in their everyday life (Bernstein, 2011): mind is not superior to substance and "thinking is only one of the things people do" (Nicolini, Gherardi, Yanow, 2003, p. 8). The entirety of mundane human actions, which interplays with emotion and cognition (Cohen, 2007), is important in order to appreciate the human existence. Contemporary theories of practice owe much to the works of Martin Heidegger and Ludwig Wittgenstein, whose significant achievement is pointing to the primacy of practice that is "prior to any explicit interpretation" (Sandberg, Tsoukas, 2015, p. 187). Heidegger's philosophical works brought new understanding of being in the world - not as an external observer to reality but both subjective and objective coexisting as one inseparable world (Nicolini et al., 2003); whereas Wittgenstein's philosophical investigations stimulated a new understanding of how language is embedded in human social practices (Hendry, 2000). Building upon the works of these philosophers, Pierre Bourdieu developed the framework of social ontology that connects cognitive and social in the fields of symbolic structures (Everett, 2002), and Ted Schatzki elaborates on practices as nexuses of activities comprised of doings and sayings, which enable us to understand who we are and what we do (Sandberg, Tsoukas, 2015).

As it stands, practice theory grew from the critique of scientific rationality 
(Sandberg, Tsoukas, 2011), the ontological duality of body and mind, and detachment of individuals and their social environment. Given the richness and variety of philosophical and sociological investigations of sociality, there is no one unified approach as to what stands behind social activities and practice - like G. Spaargaren, M. Lamers, and D. Weenink (2016) suggest, it is more a family of interrelated approaches than a single theory of practice. Also, there are different ways and criteria of how to demarcate the domain of practice theorising (Schatzki, 2016). The organisational research that is ascribed to practice theorising ranges from the kinds of theories such as actor-network theory (ANT) (Gherardi, 2000), which views social action as constantly shifting networks of relationships (Latour, 2005) but does not conceptualise activities as practice, to other kinds of theories such as situated learning, which focuses on learning, thinking and knowing as "relations among people engaged in activity in, with, and arising from the socially and culturally structured world" (Lave, 1991, p. 67), or strategy-as-practice, which treats strategy as microlevel action (Jarzabkowski, 2005) and explicitly refers to these activities as practices. It may also be confusing that there are other approaches which claim to focus on practices, but which follow an economic view and fall outside of the scope of the social theories of practice (Jarzabkowski et al., 2015); for example, the practice-based approach used by P. Bromiley and D. Rau (2014) or, in part, ethnomethodology (Sandberg, Tsoukas, 2015). One general idea unifying practice theorising in organisational science is that practice theories share interest in human activities rooted in social practices (Schatzki, 2016), while there may be disagreement on how those activities are conceptualised and what, in addition to activities, comprise those practices (Schatzki, 2017).

\section{What is "theory" and what is "practice"?}

The traditional notion of "practice" suggests that "practice is what theory is not" (Hirschauer, 2017, p. 91). For this reason, the joint use of "theory" and "practice" may be perceived as an oxymoron. Such a perception comes along with a commonsensical understanding of practiceoriented organisational research, which provides a descriptive account of some phenomenon and of what people do in selected contexts (Sandberg, Tsoukas, 2015), or, in other words, the empirical account of practices in organisations (Feldman, Orlikowski, 2011). It is a popular misperception that studying practice can only reach as far as the descriptive accounts of what people do. The transition from mundane organisational activities to a higher level of abstraction nevertheless is a distinct characteristic of practice theory approach - practice "theorising makes theory derivative of practice" (Sandberg, Tsoukas, 2015, p. 188). Therefore, practice concept is not the opposite of theory, but a source of theoretical conceptualisations in practice theorising.

What is commonly claimed to constitute theory in management research are middle-range theories, generic and ordered assertions (Whetten, 1989), which allow to explain and predict certain 
phenomena, events or behaviour. Such understanding of theory is close to what was long accepted as the only way to contribute to theory by using 'a "causal functional" approach of the natural sciences' (Schutz, 1954, p. 259) and what has been pushed forward as an ideal to be adopted by social sciences. In sociological language, the meaning of theory is more polysemic: it can include the "construction of propositions" or explanation of a particular phenomenon but may also infer an "ongoing dialogue with some classical texts" or the "lexica and schemata" of the social world (Abend, 2008, p. 175) among other uses of the concept. In the case of practice theory, what I infer by theory, is a type of social ontology (Feldman, Orlikowski, 2011), i.e. the "general and abstract account" (Schatzki, 2001a, p. 12) of the social world. Defining such a notion of theory, G. Abend (2008) aptly uses a German word "Weltanschauung" (in English: "worldview"), i.e., a general perspective through which we interpret the world. This way practice theory in organisational science is not a set of explanatory or predictive statements, but a perspective (Sandberg, Tsoukas, 2015) that serves as a general epistemological and ontological background to research and it is not tied to any specific organisational phenomena or research method.

As it is apparent, the focus of practice theory is organisational practices, defined as human actions that are embodied in material worlds, i.e. "arrays of human activities", which depend "on shared skills or understanding" and "mediated by artefacts, hybrids, and natural objects" (Schatzki, 2001a, pp. 11-12). Practices could be understood as the retention of particular ways of how we select and control those selections of perceived possibilities - the choices we make and the other potential ways that we exclude (Fairclough, 2003). In both Lithuanian or English languages, there is no linguistic distinction between the broader phenomenon of practice and specific activities - the word "practices" (in Lithuanian: "praktikos") may imply one of those meanings depending on the context. However, I would like to make this important distinction by using the example of German language, which has two distinct words linking practice to two different meanings - "Praxis" and "Praktiken". Practice as a "Praxis" implies "the whole of human action" (Reckwitz, 2002, p. 249) and refers to the actual and ordinary activities of humans, "what people do in practice" (Whittington, 2006, p. 619). Whereas practice as "Praktiken" is a set of multiple "praxis" that are performed, and refers to more interconnected elements of organisational activities, such as material objects used in those activities, knowledge, emotions and motivation (Reckwitz, 2002). The socio-ontological concept of practice as "Praktiken" refers to social activities based on shared understanding (Schatzki et al., 2001): the ways of doing and social "collectively constructed orders" (Rasche, Chia, 2009, p. 6) drawing on "unconscious tacit understanding" (Langley, Abdallah, 2011, p. 220). It varies nevertheless in different theoretical approaches to practice how they conceptualise activities that constitute human practice: it may be that only routinised and patterned activities are viewed as being a part of social practices; alternatively, routines are no different from irregularities and unique activities and all of them 
are part of social practices (Rouse, 2007; Schatzki, 2001b).

Based on those two understandings of practice - as "Praxis" and as "Praktiken" in the first, narrower sense, the concept of practice would entail activities, routines, situated actions (Gherardi, 2008) and a wide range of human activities in contexts; in the second sense, practices comprise interconnected and organised actions (Spaargaren et al., 2016) and form bundles (Schatzki, 2002), which are the product of bodily movements, understanding, desiring and using material objects (Reckwitz, 2002). The specific context in which scientists place their explorations of practices points to more subtle characteristics of practices, and such an open-ended definition may even be promoted in the name of plurality of worldviews and ontological constructions (Nicolini, 2012). Nevertheless, most of practice theorising goes beyond the "praxis" alone and bases their analysis on the nets of practices embedded in contexts and collectively maintained over time.

\section{Socio-ontological characteristics of practice}

Organisational practices are situated in material, social and individual interconnectedness, and there are three important characteristics that define them - activity, sociality, and embeddedness in the material world; thus, further they are discussed in more detail.

Activity. Human activity is commonly perceived as reducible to visible physical movements. However, there is more to social practice than what we explicitly see in human actions (Sandberg, Tsoukas, 2015), practices build on "symbolic structures of meaning" (Reckwitz, 2002, p. 244). Different meaning may be implied behind the visibly similar human activities and similar meaning may be expressed by different actions. However, it is not only bodily movements which count as activities - what we do and what we say are both inherent parts of practices (Schatzki, 1996). Words carry the meanings, and, same as with bodily activities, different meaning may be implied within the same linguistic expression. Language itself may be the tool for performing certain actions (Fairclough, 2003) and this could only be interpreted within its context and by paying attention to other phenomena that organise it. T. R. Schatzki (2005) distinguished three types of social phenomena that organise and hold practices together: understanding, rules and teleo-affective structure. Practices are organised by practical intelligibility, or, the so-called "understanding" of how and what it makes sense to do and say. Social practices are centred around shared understanding (Schatzki, 1988), which is "grounded on taken-for-granted background practice" (Taylor, 1993), as cited by J. Sandberg and H. Tsoukas (2015, p. 186). These are explicit principles of practicing (Schau, Muñiz Jr, Arnould, 2009), which we accept as a proper way of doing things and which are not a matter of interpretation but "following a rule" (Wittgenstein, 2009, p. \$202). Lastly, teleo-affective structure is the phenomenon that organises practices through emotional engagement and commitment of people to their activities - "ends and purposes" (Schau et al., 2009 , p. 31). General beliefs are part of the 
teleo-affective structures, but sometimes are separated as a fourth distinct organising phenomenon - "general understanding" (Schatzki, 2002).

Sociality. Practice theories take a middle ground view on sociality between subjectivist and objectivist explanation of the social (Spaargaren et al., 2016), or in other words, between rational choice and norms-oriented approaches (Reckwitz, 2002). What the theories of rational choice (purposeful action) define as social order is a combination of individual motives; whereas norms-oriented theories of action treat sociality as a matter that is agreed by consensus - "collective norms and values, i.e. to rules which express a social 'ought"' (Reckwitz, 2002, p. 245) and does not depend on human will. The social as viewed through a practice lens moves away from such opposition between agency and structure to the totality of the concept, which "has an existence beyond that of its parts" (Schatzki, 1996, p. 2). In the vocabulary of practice theory, sociality is dynamic and interrelated coexistence of human beings - "interrelated ongoing lives" (Schatzki, 1988, p. 243) emerging "through people's recurrent actions" (Feldman, Orlikowski, 2011). The social world is interconnected human existence shaped by their engagement in the community (Schatzki, 2017) and by the performance of shared practices (Schatzki, 1988). Social orders are shaped by practices but also are those which constrain the practices themselves (Ortner, 2006). The individual and the social do not reside as distinct but as one single level of reality without higher (social structure) or lower (individual) domains (Schatzki, 2016) and without separation of individual interests and collective reality. Social life is what we do and experience as a part of coexistence with other human beings.

Materiality. Materiality is the other important consideration of practical activities and may be encompassed in practice theorising in several ways. One, materiality may be treated as equally relating to human agents and material objects. Such understanding is associated with the webs of material objects and humans that are carried on by practices as conceived in the actor-network theory approach (Law, 2009). Materiality is part of the whole of practices, which are combinations of "materials, competences and meanings" (Shove, Pantzar, Watson, 2012, p. 24). While on a different account, material objects are relevant to practical arrangements as a mediating part of human practices, i.e. practices are "construed as materially mediated nexuses of activity" (Schatzki, 2001a, p. 20). Material objects and the sensations which are attached to those objects may activate or represent human experience and articulate virtues (Ger \& Kravets, 2009); additionally, material objects and their distribution may determine the limits of the infrastructure of human activities as well as where and what material arrangements may be anchored in organising human lives (Schatzki, 2009). What is nevertheless important to highlight here again is that there is no duality between thought and bodily experiences and there is no separate identity of body from that of mind (Rorty, 1979). Materialism, as treated by practice scholars, is dynamic experience of the matter that surrounds us, in which we are immersed, and of which we are composed (Coole, Frost, 2010). 


\section{Applying the practice theoretical Iens}

There are a few fields of organisational research, which adopted the practice theory lens more extensively than other areas: these are strategic management (strategy as practice field), organisational learning and knowledge research. Additionally, in a more broader area of management disciplines there are notable examples of applying the practice lens in the field of consumer research. Further, I provide examples of a few empirical studies that use the practice lens. It is not the aim here to present a full range of practice-based research but instead to demonstrate a selection of papers that represent a variety of micro and macro practice theorising, analytic frameworks, methods of analysis and data sources. It is worth noting, though, that all these examples are based on qualitative data analysis and that, as it stands now, practice-based studies consider qualitative research to best satisfy the need for an in-depth look and contextualisation.
Strategy as practice is probably the best-known area in organisational research that employs practice theorising. It relates to a wide range of dimensions of strategy formation (Langley, 2007) and focuses on micro-level activities and on what people do in their daily strategizing in connection with a broader phenomenon of strategy (Whittington, 2006). The view on strategy through the practice lens enables more complexity and diversity of scholarly perspectives, and for practitioners, a way of thinking about strategy as an ongoing socially embedded change (Hendry, 2000). One of the frameworks that strategy-aspractice scholars adopt in their empirical studies is based on the vocabulary suggested by R. Whittington (2006) - a trio consisting of practitioners, practices, and praxis, also referred to as "3P framework" (Paroutis, Heracleous, Angwin, 2016) (see Figure 1). Thus, 3Ps identify practitioners (actors, strategists who perform the practices), praxis (activities, routines, daily strategy making) and practices (tacit and explicit rules, procedures, cultures) and their interconnections as key areas that

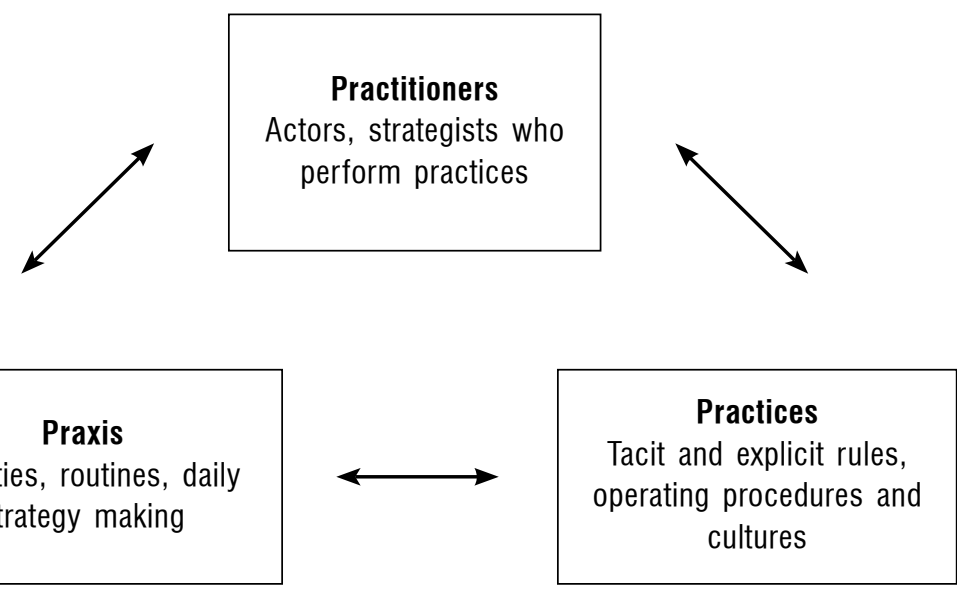

Fig. 1. The 3P framework based on R. Whittington (2006). 
strategy-as-practice scholars focus on in their analyses. For example, D. Angwin, S. Paroutis, and S. Mitson (2009) studied strategizing activities of senior strategy executives and whether these activities "help organizations become more agile” (p. 75). The authors used in-depth interview and archival data and the $3 \mathrm{P}$ framework to structure their analysis and identified how UK strategists' work differs compared to their US counterparts in terms of their embeddedness in business, involvement in implementation, wielding of power and the trajectories of their carrier. What the practice lens here helped do was to uncover the actual activities and capabilities of strategists and their interconnectedness instead of preconceived scientific notions. I nevertheless would to like to emphasise that the 3P framework itself is more a vocabulary and a highlight of the units of analysis to pay attention to; it may be used in different ways and the framework itself does not constitute the practice lens.

The strategy-as-practice study by $\mathrm{P}$. Jarzabkowski and D. Seidl (2008) used observations, documents, interviews and thematic analysis to trace the process of how strategy meetings stabilise or destabilise strategic orientations and demonstrated how meeting routines shape strategic outcomes. In yet another research study, D. Seidl and F. Werle (2018) drew on the data from two longitudinal case studies of inter-organisational sensemaking and looked at how actors are selected and how the selection then affects the sensemaking process of strategic meta-problems; they identified the mechanism of inter-organisational sensemaking processes, which helps to explain the outcomes of such processes. Both studies represent examples of how micro-processes at the ground level of "doing strategy" may help to understand substantive processes at the organisational or inter-organisational level.

\section{Organisational learning and know-} ing. How organisation actors work and learn in practice is often purely reflected in how these processes are described in documents (Brown, Duguid, 1991): there is much more tacit and contextual knowledge in practices than what may be written down on paper. Knowledge is not what people have in their heads (Gherardi, 2000), but what people do by working together and what they create through negotiated meaning (Gherardi, 2008). It is a discursive process mediated by material objects (Gherardi, 2006) and practice-based theorising of the creation of organisational knowledge enables those contingencies and that situational wisdom to be captured (Gherardi, 2008). A book chapter by Dvora Yanow (2015) draws on the analysis of an autobiographical account of a person who was learning to deliver newspapers when he was a boy, as well as the analysis of other secondary sources. This paper uses the "very material, bodily, and social elements" (p. 277) of the texts to enhance the understanding of learning as practice and show how the conception of a novice learner of his future practice is a part of the practice itself. Furthermore, Yanow's analysis allows for the transformation of the concept of "being a master" from the illusionary stability of being competent to practise to a continuous return to novice-ry: when any issues arise, practitioners must interrupt their regularised practices and bring the elements of their practising to focal awareness to continue their mastery. Yanow articulates the 
lifecycle of mastery-learning and urges us to rethink the notion of organisation from treating it as a container for practices to organisation being a practice itself. Another example of studying organisational learning and knowing is an ethnographic study by D. Nicolini, J. Mengis, and J. Swan (2012), which contributes to the understanding of the role of socio-material practices that these practices play in interdisciplinary collaboration. These authors use a pluralistic framework of four theoretical lenses, which complement each other and help to identify how material objects support collaborations but also how they create tensions and misunderstandings: the objects used in collaboration have no given meaning but gain and change it in the contexts, times and in relation to the people who use them, and these findings directly address practitioners - managers, who may benefit from expecting objects to have no universal meaning and probe for understanding of those meanings in order to manage conflicts in collaboration.
Consumer research. Finally, I provide an example from consumer research, which is a management discipline outside of organisation studies, however, I see it useful to familiarise with how T. R. Schatzki (1996) social ontology of practice may be employed in an empirical study of practices. H. J. Schau et al. (2009) studied brand community practices and used the analytical framework built on the three phenomena that hold practices together: rules, understandings and engagements (i.e., teleo-affective structures) (see Figure 2). Through the analysis of nine netnographic research studies and connecting them to the extant research of value-creation practices of brand communities, the authors come up with a list of practices organised under four themes "through which consumers realize value beyond that which the firm creates or anticipates" (p. 30). The examination of practices through their binding phenomena helped this study to reach the depth of the understanding of the mechanism how "value is manifest

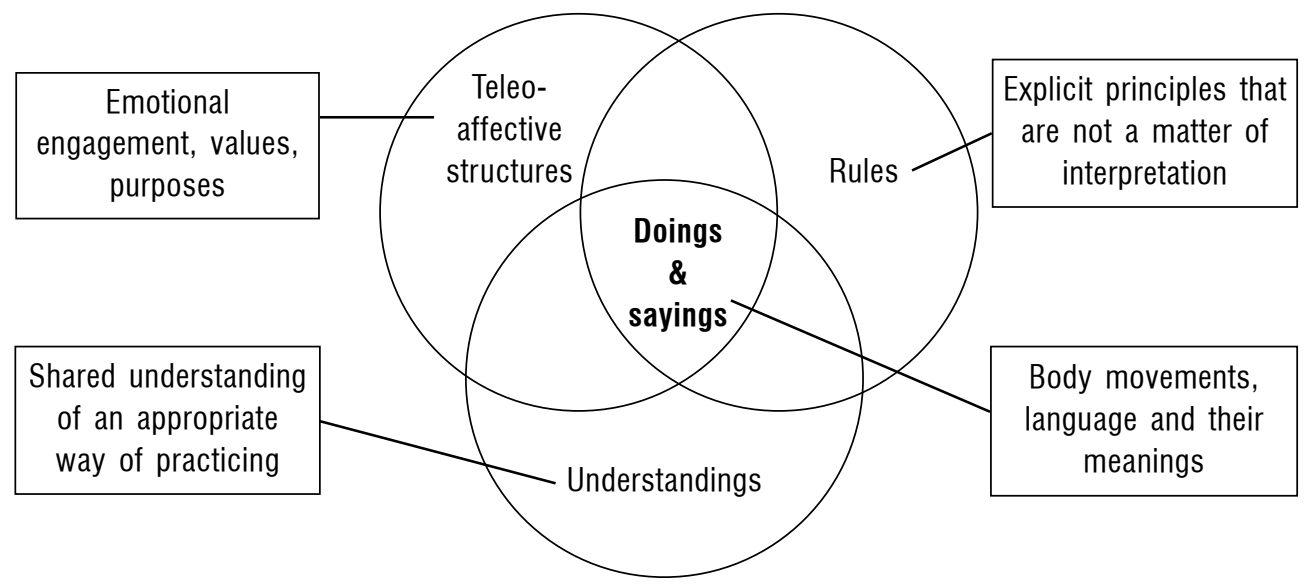

Fig. 2. Three phenomena that hold social practices Source: based on T. R. Schatzki (1996). 
Table 1. Empirical studies using practice lens

\begin{tabular}{|c|c|c|c|}
\hline $\begin{array}{l}\text { Empirical } \\
\text { study }\end{array}$ & $\begin{array}{l}\text { Perspective / } \\
\text { research field }\end{array}$ & Data sources & Data analysis \\
\hline $\begin{array}{l}\text { Angwin et al. } \\
(2009)\end{array}$ & $\begin{array}{l}\text { Strategy as } \\
\text { practice }\end{array}$ & $\begin{array}{l}\text { In-depth interviews and archival } \\
\text { data }\end{array}$ & $\begin{array}{l}\text { Inductive identification of recurrent } \\
\text { themes and structuring based on } 3 \mathrm{P} \\
\text { framework (Whittington, 2006) linking } \\
\text { practitioners, praxis and practices }\end{array}$ \\
\hline $\begin{array}{l}\text { Jarzabkowski } \\
\text { and Seidl } \\
(2008)\end{array}$ & $\begin{array}{l}\text { Strategy as } \\
\text { practice }\end{array}$ & $\begin{array}{l}\text { Observation, documents, } \\
\text { interviews }\end{array}$ & Thematic analysis, process tracing \\
\hline $\begin{array}{l}\text { Seidl and } \\
\text { Werle (2018) }\end{array}$ & $\begin{array}{l}\text { Strategy as } \\
\text { practice }\end{array}$ & $\begin{array}{l}\text { Longitudinal ethnographic case } \\
\text { studies: observation, interviews, } \\
\text { documents and pictures of artefacts }\end{array}$ & $\begin{array}{l}\text { Processual analysis of actors, actions, } \\
\text { motivations, reactions and their change } \\
\text { over time }\end{array}$ \\
\hline Yanow (2015) & $\begin{array}{l}\text { Organizational } \\
\text { learning }\end{array}$ & $\begin{array}{l}\text { Secondary data: a book and other } \\
\text { texts }\end{array}$ & Narrative analysis \\
\hline $\begin{array}{l}\text { Nicolini et al. } \\
(2012)\end{array}$ & $\begin{array}{l}\text { Organizational } \\
\text { knowing }\end{array}$ & $\begin{array}{l}\text { Focused ethnography: observation, } \\
\text { interviews, videos and visuals }\end{array}$ & Inductive and iterative analysis \\
\hline $\begin{array}{l}\text { Schau et al. } \\
(2009)\end{array}$ & $\begin{array}{l}\text { Consumer } \\
\text { behaviour }\end{array}$ & $\begin{array}{l}\text { Netnography, meta-analytic litera- } \\
\text { ture review }\end{array}$ & $\begin{array}{l}\text { The analysis of practices as sayings } \\
\text { and doings linked through procedures, } \\
\text { understandings and engagements } \\
\text { (Schatzki, 1996) }\end{array}$ \\
\hline $\begin{array}{l}\text { Rosenberg } \\
\text { and Keller } \\
(2016)\end{array}$ & $\begin{array}{l}\text { Organizational } \\
\text { change }\end{array}$ & Interviews and documents & $\begin{array}{l}\text { Rules, practical understandings and } \\
\text { teleo-affective structures (Schatzki, } \\
\text { 1996) }\end{array}$ \\
\hline
\end{tabular}

in the collective enactment of practices" (p. 41). Having a large empirical database in conjunction with meta-analysis of the extant research studies allowed authors to generalise beyond the activities of single cases. Like in the case of this example in the consumer research field, the analytical disentangling of social practices and the phenomena which organise them finds use in organisational research too, e.g. in the study by Rosenberg and Keller (2016) on making sense of structural change in a public organisation.

Practice-based empirical papers use varied sources of data, of which observations and ethnographic methods is an important but not the only source of insights (see the summary of the papers discussed in this section in Table 1). It is apparent that qualitative and interpretative research dominate when studying social practices as they concern not only activities but also the meaning structures behind visible action and language.

The empirical examples of the research studies using the practice theory approach demonstrate that eliciting explanatory accounts are not superior to the development of the understanding of an organisational phenomenon. Such theoretical understanding is more than mere empirical description: it is an evaluative analysis which infers the meaning beyond the description of empirical material. Instead of concentrating on prediction, practice theorists use the language and the framework that helps "one decides what to do" (Rorty, 1981, p. 4). The world cannot be explained, 
but instead, the meaning may be inferred, and the evaluative description can be provided. The challenge for a practice scholar is that engaging in practice theorising means observing, gaining in-depth understanding of practices and making sense of what people do in practice over time, and in many cases that requires long-term engagement, such as ethnographic or longitudinal study. However, practice theorising provides more sensible results to complex and dynamic organisational environments, therefore, is more easily absorbed in practical arrangements. Practice theorising offers helpful framework and enables us to redirect our attention to mundane human activities, which otherwise tend to be taken for granted and analysed through more distant and abstract concepts. Practice theory speaks to both economic theorists, who are concerned with individual motives, and with those having sociological accounts, attempts to affirm the significance of both society and individual (Whittington, 2006) and engages them in a new agenda. It closes the gap between the flawed distinction of practitioners' work and academia, picturesquely named by Donald A. Schön as a "swampy lowland" of messy practice and "high ground" of well-defined academic issues (1987), and unites the two through a more holistic understanding of complex organisational and managerial activity arrays.

\section{Conclusions}

In this paper, the definition of practice theory has been introduced and the major characteristics of practice and practice theorising have been outlined. The concept of "practice" has a popular connotation of being a part of what organisations do but not a part of theorisations about organising practices. The theoretical and practitioners' perspectives aim to describe but do not create an abstract account of an organisational phenomenon, and practice theory as a social ontology is not to be confused with these perspectives. There are multiple streams of research that attend to practices as a focal concept, while not all of them depart from economic view on sociality, which gained a new meaning in organisational science, particularly, in practice theorising. Practice theoretical analysis attends to human actions and understanding of social human practices as embedded in materiality. Practices are what people do, and what it makes sense for them to do, and moreover, as social activities they are organised by several phenomena, such as practical intelligibility, tacit rules and emotional engagement. What practice theorising helps to achieve is to draw abstract theoretical accounts based on what and how people do things: the theoretical understanding is an evaluative description of the worlds which in return provides more practically relevant feedback to practitioners as compared to explanatory abstractions and diminishes the divide between knowledge domains of practitioners and scientists.

\section{Acknowledgements}

I would like to thank prof. Dimo Dimov and prof. Ted Schatzki for their invaluable comments on the earlier drafts of this paper. 


\section{References}

1. Abend, G. (2008). The Meaning of 'Theory' // Sociological Theory. Vol. 26, No. 2, p. 173-199. doi:10.1111/j.1467-9558.2008.00324.x.

2. Andriuščenka, J. (2008). Organizacinių pokyčiu valdymo teorijos: lyginamoji analizé, vertinimas ir taikymo ypatumai // Vadybos mokslas ir studijos-kaimo verslų ir jų infrastruktūros plètrai: mokslo darbai. Vol. 12, No. 1, p. 12-23.

3. Angwin, D., Paroutis, S., Mitson, S. (2009). Connecting up Strategy: Are Senior Strategy Directors a Missing Link? // California Management Review. Vol. 51, No. 3, p. 74-94.

4. Barney, J. (1991). Firm Resources and Sustained Competitive Advantage // Journal of Management. Vol. 17, No. 1, p. 99-120.

5. Bernstein, R. J. (2011). Praxis and Action: Contemporary Philosophies of Human Activity. Philadelphia, PA: University of Pennsylvania Press.

6. Bromiley, P., Rau, D. (2014). Towards a PracticeBased View of Strategy // Strategic Management Journal. Vol. 35, No. 8, pp. 1249-1256.

7. Brown, J. S., Duguid, P. (1991). Organizational Learning and Communities-of-Practice: Toward a Unified View of Working, Learning, and Innovation // Organization Science. Vol. 2, No. 1, pp. 40-57.

8. Cohen, M. D. (2007). Reading Dewey: Reflections on the Study of Routine // Organization Studies. Vol. 28, No. 5, pp. 773-786.

9. Coole, D., Frost, S. (2010). Introducing the New Materialisms / In New Materialisms: Ontology, Agency, and Politics, eds. D. Coole and S. Frost. - Durham and London: Duke University Press, p. 1-43.

10. Everett, J. (2002). Organizational Research and the Praxeology of Pierre Bourdieu // Organizational Research Methods. Vol. 5, No. 1, p. 56-80. doi:10.1177/1094428102051005.

11. Fairclough, N. (2003). Analysing Discourse: Textual Analysis for Social Research. - London and New York: Routledge.

12. Feldman, M. S., Orlikowski, W. J. (2011). Theorizing Practice and Practicing Theory // Organization Science. Vol. 22, No. 5, p. 1240-1253. doi:10.1287/orsc. 1100.0612 .

13. Ger, G., Kravets, O. (2009). Special and Ordinary Times: Tea in Motion / In Time, Consumption and Everyday Life: Practice, Materiality and Culture, eds. E. Shove, F. Trentmann and R. Wilk. - Abigdon, Oxon; New York, NY: Routledge.

14. Gherardi, S. (2000). Practice-Based Theorizing on Learning and Knowing in Organizations // Organization. Vol. 7, No. 2, p. 211-223. doi:10.1177/135050840072001.

15. Gherardi, S. (2006). Organizational Knowledge: The Texture of Workplace Learning. - Malden, Mass.: Blackwell.

16. Gherardi, S. (2008). Situated Knowledge and Situated Action: What Do Practice-Based Studies Promise // The SAGE Handbook of New Approaches in Management and Organization. Vol., No., p. 516-525.

17. Hendry, J. (2000). Strategic Decision Making, Discourse, and Strategy as Social Practice // Journal of Management Studies. Vol. 37, No. 7, p. 955-978.

18. Hirschauer, S. (2017). Praxis Und Praktiken / In Handbuch Körpersoziologie: Band 1: Grundbegriffe Und Theoretische Perspektiven, eds. R. Gugutzer, G. Klein and M. Meuser. - Wiesbaden: Springer Fachmedien Wiesbaden, pp. 91-96.

19. Jarzabkowski, P. (2005). Strategy as Practice: An Activity-Based Approach. - London, Thousand Oaks, New Delhi: SAGE Publications.

20. Jarzabkowski, P., Kaplan, S., Seidl, D., Whittington, R. (2015). On the Risk of Studying Practices in Isolation: Linking What, Who, and How in Strategy Research // Strategic Organization. Vol. 14, No. 3, pp. 248-259.

21. Jarzabkowski, P., Seidl, D. (2008). The Role of Meetings in the Social Practice of Strategy // Organization Studies. Vol. 29, No. 11, p. 1391-1426.

22. Juozelis, E. (2016). Sociosofija ir praktoteorija // Filosofija. Sociologija. Vol., No. 3, p. 231-239.

23. Langley, A. (2007). Process Thinking in Strategic Organization // Strategic Organization. Vol. 5, No. 3, pp. 271.

24. Langley, A., Abdallah, C. (2011). Templates and Turns in Qualitative Studies of Strategy and Management / In Building Methodological Bridges, eds. D. J. Ketchen and D. D. Bergh. Vol. 6, - Bingley, UK: Emerald Group Publishing Limited, pp. 201 - 235.

25. Latour, B. (2005). Reassembling the Social: An Introduction to Actor-Network-Theory. - Oxford Clarendon: Oxford University Press.

26. Lave, J. (1991). Situating Learning in Communities of Practice / In Perspectives on Socially 
Shared Cognition, eds. L. B. Resnick, J. M. Levine and S. D. Teasley. - Washington, DC, US: American Psychological Association, pp. 63-82.

27. Law, J. (2009). Actor Network Theory and Material Semiotics / In The New Blackwell Companion to Social Theory, ed. B. S. Turner. - Malden, MA and Oxford: Wiley-Blackwell, pp. 141-158.

28. Lawrence, P. R., Lorsch, J. W. (1986). Organization and Environment: Managing Differentiation and Integration. - Boston, MA: Harvard Business School Press.

29. Miettinen, R., Samra-Fredericks, D., Yanow, D. (2009). Re-Turn to Practice: An Introductory Essay // Organization Studies. Vol. 30, No. 12, pp. 1309-1327.

30. Nelson, R. R., Winter, S. G. (2009). An Evolutionary Theory of Economic Change. - Cambridge, Massachusetts, and London, England: The Belknap Press of Harvard University Press.

31. Nicolini, D. (2011). Practice as the Site of Knowing: Insights from the Field of Telemedicine // Organization Science. Vol. 22, No. 3, p. 602-620.

32. Nicolini, D. (2012). Practice Theory, Work, and Organization: An Introduction (1st ed.). - Oxford: Oxford University Press.

33. Nicolini, D., Gherardi, S., Yanow, D. (2003). Introduction: Toward a Practice-Based View of Knowledge and Learning in Organization / In Knowing in Organizations: A Practice-Based Approach, eds. D. Nicolini, S. Gherardi and D. Yanow. - London: M.E. Sharpe.

34. Nicolini, D., Mengis, J., Swan, J. (2012). Understanding the Role of Objects in Cross-Disciplinary Collaboration // Organization Science. Vol. 23, No. 3, pp. 612-629. doi:10.1287/ orsc. 1110.0664 .

35. Ortner, S. B. (1984). Theory in Anthropology since the Sixties // Comparative Studies in Society and History. Vol. 26, No. 1, p. 126-166.

36. Ortner, S. B. (2006). Anthropology and Social Theory: Culture, Power, and the Acting Subject. - Durham and London: Duke University Press.

37. Parmigiani, A., Howard-Grenville, J. (2011). Routines Revisited: Exploring the Capabilities and Practice Perspectives // Academy of Management Annals. Vol. 5, No. 1, pp. 413-453.

38. Paroutis, S., Heracleous, L., Angwin, D. (2016). Practicing Strategy: Text and Cases. - London: Sage.

39. Rasche, A., Chia, R. (2009). Researching Strategy Practices: A Genealogical Social Theory Per- spective // Organization Studies. Vol. 30, No. 7, p. 713-734. doi:10.1177/0170840609104809.

40. Reckwitz, A. (2002). Toward a Theory of Social Practices: A Development in Culturalist Theorizing // European Journal of Social Theory. Vol. 5, No. 2, pp. 243-263.

41. Rorty, R. (1979). Philosophy and the Mirror of Nature -Princeton, NJ: Princeton University Press.

42. Rorty, R. (1981). Method, Social Science, and Social Hope // Canadian Journal of Philosophy. Vol. 11, No. 4, p. 569-588.

43. Rosenberg, A., Keller, M. (2016). Making Sense of Organizational Structure Change: A PracticeBased Approach // Baltic Journal of Management. Vol. 11, No. 4, pp. 452-472. doi:10.1108/ BJM-12-2015-0243.

44. Rouse, J. (2007). Practice Theory. Division I Faculty Publications, (Paper 43). Internet access: $\quad<$ https://wesscholar.wesleyan.edu/div1 facpubs/43/> [accessed March 16, 2018].

45. Sandberg, J., Tsoukas, H. (2011). Grasping the Logic of Practice: Theorizing through Practical Rationality // Academy of Management Review. Vol. 36, No. 2, p. 338-360.

46. Sandberg, J., Tsoukas, H. (2015). Practice Theory: What It Is, Its Philosophical Base, and What It Offers Organization Studies / In The Routledge Companion to Philosophy in Organization Studies, eds. R. Mir, H. Willmott and M. Greenwood [accessed February 11, 2018].

47. Schatzki, T. R. (1988). The Nature of Social Reality // Philosophy and Phenomenological Research. Vol. 49, No. 2, p. 239-260.

48. Schatzki, T. R. (1996). Social Practices: A Wittgensteinian Approach to Human Activity and the Social. - Cambridge: Cambridge University Press.

49. Schatzki, T. R. (2001a). Introduction: Practice Theory / In The Practice Turn in Contemporary Theory, eds. T. R. Schatzki, K. Knorr-Cetina and E. von Savigny. - London, New York: Routledge.

50. Schatzki, T. R. (2001b). Practice Mind-Ed Orders / In The Practice Turn in Contemporary Theory, eds. T. R. Schatzki, K. Knorr-Cetina and E. von Savigny. - London, New York: Routledge.

51. Schatzki, T. R. (2002). The Site of the Social: A Philosophical Account of the Constitution of Social Life and Change. - Philadelphia: Penn State University Press.

52. Schatzki, T. R. (2005). Peripheral Vision: The Sites of Organizations // Organiza- 
tion Studies. Vol. 26, No. 3, pp. 465-484. doi:10.1177/0170840605050876.

53. Schatzki, T. R. (2009). Timespace and the Organization of Social Life / In Time, Consumption and Everyday Life: Practice, Materiality and Culture, eds. E. Shove, F. Trentmann and R. Wilk. - Oxford, UK, and New York, NY: Berg, p. 35-48.

54. Schatzki, T. R. (2016). Practice Theory as Flat Ontology / In Practice Theory and Research: Exploring the Dynamics of Social Life, eds. G. Spaargaren, D. Weenink and M. Lamers. Abigdon, Oxon; New York, NY: Routledge.

55. Schatzki, T. R. (2017). Practices and People // TPA-Teoria e Prática em Administração. Vol. 7, No. 1, pp. 26-53.

56. Schatzki, T. R., Knorr-Cetina, K. D., von Savigny, E. (2001). The Practice Turn in Contemporary Theory. - London, New York: Routledge.

57. Schau, H. J., Muñiz Jr, A. M., Arnould, E. J. (2009). How Brand Community Practices Create Value // Journal of Marketing. Vol. 73, No. 5, p. 30-51.

58. Schön, D. A. (1987). Educating the Reflective Practitioner: Toward a New Design for Teaching and Learning in the Professions. - Oxford and San Francisco: Jossey-Bass.

59. Schutz, A. (1954). Concept and Theory Formation in the Social Sciences // The Journal of Philosophy. Vol. 51, No. 9, pp. 257-273. doi:10.2307/2021812.

60. Seidl, D., Werle, F. (2018). Inter-Organizational Sensemaking in the Face of Strategic MetaProblems: Requisite Variety and Dynamics of Participation // Strategic Management Journal. Vol. 39, No. 3, pp. 830-858.

61. Shove, E., Pantzar, M., Watson, M. (2012). The Dynamics of Social Practice: Everyday Life and How It Changes. - London, Thousand Oaks, New Delhi: Sage.

62. Spaargaren, G., Lamers, M., Weenink, D. (2016). Introduction: Using Practice Theory to Research Social Life / In Practice Theory and Re- search: Exploring the Dynamics of Social Life, eds. G. Spaargaren, D. Weenink and M. Lamers. - Abigdon, Oxon; New York, NY: Routledge.

63. Taylor, C. (1993). To Follow a Rule / In Bourdieu: Critical Perspectives, eds. C. Calhoun, E. Lipuma and M. Postone. Vol. 6, - Chicago and Cambridge: University of Chicago Press and Polity Press, pp. 45-60.

64. Teece, D. J., Pisano, G., Shuen, A. (1997). Dynamic Capabilities and Strategic Management // Strategic Management Journal. Vol. 18, No. 7, p. 509-533.

65. Valantiejus, A. (2006). Socialinès struktūros samprata // Sociologija. Mintis ir veiksmas. Vol. 18, No. 2.

66. Valantiejus, A. (2013). Šiądienos kritinès teorijos klausimu // Sociologija. Mintis ir veiksmas. Vol. 33, No. 2.

67. Van Inwagen, P. (2001). Ontology, Identity, and Modality: Essays in Metaphysics. - Cambridge: Cambridge University Press.

68. Whetten, D. A. (1989). What Constitutes a Theoretical Contribution? // Academy of Management Review. Vol. 14, No. 4, p. 490-495.

69. Whittington, R. (2006). Completing the Practice Turn in Strategy Research // Organization Studies. Vol. 27, No. 5, pp. 613-634. doi:10.1177/0170840606064101.

70. Williamson, O. E. (1989). Transaction Cost Economics / In Handbook of Industrial Organization, eds. S. R. and W. R. Vol. 1, - Amsterdam, San Diego, Oxford, London: Elsevier Science Publishers, pp. 135-182.

71. Wittgenstein, L. (2009). Philosophical Investigations. Trans. G. E. M. Anscombe, P. M. S. Hacker and J. Schulte, 4th ed. - Chichester, UK: John Wiley \& Sons.

72. Yanow, D. (2015). After Mastery / In The Emergence of Novelty in Organizations, eds. R. Garud, B. Simpson, A. Langley and H. Tsoukas. - Oxford: Oxford University Press, p. 272.

The paper submitted: April 10, 2018 Prepared for publication: June 29, 2018 
Irina LIUBERTĖ

\section{PRAKTIKOS TEORIJOS ORGANIZACINIUOSE TYRIMUOSE KAIP PRAKTIŠKAI ISISAVINAMŲ ŽINIỤ ŠALTINIS}

\section{Santrauka}

Mokslinès teorijos tradiciškai remiasi ekonominèmis arba institucinemis prielaidomis ir susiduria su praktinio teorijų pritaikymo sunkumais (Gherardi, 2008). Šis tradicinis teorinis supratimas aktualus ir vadybos srityje, kur vyrauja individualizmo paradigma pagrịstos organizacinès elgsenos teorijos. Atskirtị tarp teorinių ir praktinių žinių nesėkmingai bandoma mažinti skatinant mokslininkų ir praktikų bendradarbiavimą bei efektyvesnę mokslinių teorijų komunikaciją (Sandberg, Tsoukas, 2011), bet išlaikant nepakitusias ontologines prielaidas. Tačiau jau kurị laiką populiarèja alternatyvus mokslinių teorijų kūrimo požiūris, kuris organizacijų praktikas laiko mokslo ištakų šaltiniu (Gherardi, 2008; Nicolini, 2012; Ortner, 1984) ir taip nutolsta nuo tradicinio individo ir socialinių struktūrų atskyrimo bei praktikos ir teorijos supriešinimo. Lietuvos filosofinèje literatūroje praktikos teorija ịvardijama kaip "praktoteorija“ - alternatyvi „akademiné nuostata“ (Juozelis, 2016, 231 p.), o sociologinèje literatūroje analizuojamas praktinis socialinių paradigmų „posūkis“ (Valantiejus, 2006). Tuo tarpu vadybinès praktikos teorijos ir empiriniai tyrimai vis dar skinasi kelią.

Šiame straipsnyje siekiama pateikti alternatyvą tradiciniam mokslinès teorijos supratimui: jame pristatoma praktikos teorija ir jos ištakos (Everett, 2002; Hendry, 2000; Nicolini, 2011; Nicolini et al., 2003; Sandberg, Tsoukas, 2015), jos sąsajas su kitomis teorijomis (Gherardi, 2000; Jarzabkowski et al., 2015; Miettinen et al., 2009; Sandberg, Tsoukas,
2015), jos pagrindinio analizès vieneto - praktikų apibrèžimas ir esminès charakteristikos (Fairclough, 2003; Langley, Abdallah, 2011; Reckwitz, 2002; Rorty, 1979; Schatzki, 2001a, 2002, 2009; Spaargaren et al., 2016; Whittington, 2006). „Praktika kasdienejje kalboje suprantama kaip priešprieša teorijai“" (Hirschauer, 2017), todèl kai kuriuose empiriniuose darbuose organizacinių praktikų analizė apsiriboja empiriniu jų aprašymu (Feldman, Orlikowski, 2011). Socialinė praktikos teorija neapsiriboja vien aprašomuoju tyrimu, bet jungia ir papildo ekonominị ir socialinị požiūrius (Parmigiani, Howard-Grenville, 2011; Whittington, 2006) ir taip siekia sukurti teorinius žmonių veikla pagrịstus praktinio pasaulio vertinimus. Veikla praktikos teorijoje suprantama kaip išreikšta per fizinius ir kalbos aktus bei jų prasminę reikšmę (Reckwitz, 2002; Schatzki, 1996) ir pasižymi socialiniu (Ortner, 2006; Reckwitz, 2002; Schatzki, 2017; Spaargaren et al., 2016) ir materialiniu integruotumu (Law, 2009; Schatzki, 2001a). Organizacinès praktikos - tai kasdieniai darbuotojų atliekami veiksmai, kuriuos jie atlieka, vadovaudamiesi savo supratimu, kuris formuojasi socialineje plotmeje jungiamas praktinio supratingumo, numanomų taisyklių ir emocinio įsitraukimo (Schatzki, 1988, 2002; Schau et al., 2009; Wittgenstein, 2009, p. \$202). Analitinès praktikos teorijos rezultatai leidžia kurti naujas vadybos ir organizacijų teorijas, kurios betarpiškiau ịsisavinamos praktikų ir sumažina atskirtị tarp mokslinio ir praktinio pažinimo (Rorty, 1981; Schön, 1987). 